bed-bug had been indicated by Major Rogers as the probable agent in the transmission of the disease, while Major Donovan considered it more probable that another bug, Conorhinus rubrofasciatus, was the means of disseminating the parasite. The bare fact that the parasite developed in the bed-bug so far as its flagellated, herpetomonad stage was not in itself a decisive proof that the bed-bug was responsible for its transmission; and from the telegram received it can only be supposed that Captain Patton has completed his former investigations on the development of the parasite, and has obtained definite experimental proof of its transmission by the agency of the bedbug.

The recent investigations of Dr. Wenyon on the allied parasite, Leishmania tropica, the cause of Oriental sore, make it probable that in this case the transmitting agent is a mosquito or a sand-fly (Phlebotomus sp.), sometimes also a house-fly, which may carry the infection mechanically, i.e. not as a true host. In North Africa and Southern Europe another species of these parasites is known, which is believed by its discoverer, Dr. Nicolle, to be primarily a parasite of dogs, and to be transmitted by some means from dogs to human beings, especially children, whence it has been given the name $L$. infantum. Dr. C. Basile in Italy has succeeded recently in transmitting this species experimentally by means of fleas. Further details of Captain Patton's investigations will be awaited with interest.

\section{LORD LISTER, O.M., F.R.S.}

$\mathrm{B}^{\mathrm{Y}}$ the death of Lord Lister, the world has lost one of its greatest men, and one who, without any question, conferred more benefits on humanity than any man had ever done before. His great achievement was no doubt the revolution which he carried out in the science and practice of surgery by his investigations into the causes of septic disease, and one has only to look back at the state of surgery up to the time when he began his work to gain some idea of the enormous advance which followed.

From the earliest ages the fatal consequences of wounds, whether occurring accidentally or as a result of an operation, have occupied the minds of all those who had to do with their treatment, and all sorts of attempts have been made to obviate these evils. The practice of the ancient writers was not to keep away noxious agents which interfered with the healing of wounds, as was Lister's conception, but to make the wound heal, and substances were applied to make the flesh grow, others to make the growing flesh firm, and others again to make the wound cicatrise. Amid these attempts, the tendency of the wound itself towards healing was almost entirely lost sight of; nevertheless, there were surgeons who, from time to time, were bold enough or had insight enough to protest against these views and to point out that it is to nature itself that one must attribute the ultimate healing of the wound. However, but little attention was paid to these writers, and the practice of treating the supposed poisonous state of the surface of the wound and of inducing healing by various applications still held its own.

Paracelsus was the first who came nearest the modern ideas; he supposed that there is a juice distributed in the body which keeps the various tissues in good health and repairs them when injured, and he held that the whole aim of the surgeon ought to be to prevent alterations in this liquid, these alterations resulting mainly from contact with air. Medical applications are only of use in so far as they preserve this juice and prevent its corruption.

NO. 2208, VOL. 88]
Similar views were held by Ambroise Paré, and it was chiefly by the writings and teachings of these two men that the position of nature as an agent in healing wounds was more fully recognised. The tendency after that time was to look on the contact of the air with the wound as the source of the main trouble, and after the chemical constitution of the air was discovered, it was the oxygen in the air which was chiefly blamed for the decomposition which took place in the wounds; indeed, this view was still held verv widely when Lister began his researches on the prevention of sepsis.

The first result of these views was that enormous quantities of dressings were applied over the wounds and left unchanged for a long time, with a view of excluding the air. At the end of the eighteenth century and the beginning of the nineteenth, other methods of treatment were employed, which yielded very much better results than the older ones. One of the earliest of these methods was simple water dressing, and this was followed by irrigation, by the use of the water-bath, and in some cases by the addition of various antiseptic substances to the water so employed. Others came to the conclusion that it was best to leave the wounds open, others that healing by scabbing should be promoted, while the fear of the effect of air on wounds led to the introduction, in 1816 , of subcutaneous surgery. About the middle of last century various antiseptic substances were a good deal employed, especially in France-balsams, chlorine, alcohol, chloride of zinc, iodine; and, very shortly before Lister's first publication, carbolic acid was advocated by Lemaire as an application to wounds. None of these antiseptic substances were, however, used on any definite scientific ground or with any definite method, and the result was, though a certain amount of improvement may have occurred, nothing like that which was brought about by Lister's systematic work was attained.

It is quite unnecessary to go into the details of that work; that has already been done in these columns and elsewhere. Lister was the subject of an article in the NATURE series of "Scientific Worthies" on May 7, I896 (vol. liv., p. I), and his collected works were reviewed in NATURE of February I7, I9I0. It may be said that, from the time Lister was a student, his mind had been occupied with the terrible fatal results which so constantly followed operations, however perfectly they were conducted, and he had definitely come to the conclusion that these troubles were associated with, and indeed the result of, the putrefactive changes which occurred in the blood and serum in the wound. $\mathrm{He}$ felt that if only these putrefactive changes could be avoided, the dangers which resulted would, in all probability, also disappear. So long as the view was held that these changes were due to the contact of the oxygen of the air with the discharges, the matter seemed hopeless, because it seemed impossible to perform an operation under conditions which would exclude the oxygen of the air. When, however, Pasteur in his work on "Spontaneous Generation," demonstrated that the oxygen of the air was quite unable to cause fermentative changes in organic fluids, and that these changes were due to living particles which fell into these fluids from the air, these particles belonging to the class of bacteria, the outlook became much more promising, for it was quite a different matter to have to do with particles which were simply floating in the air, and were often in small numbers and even entirely absent, than with gaseous substances which could penetrate everywhere.

Two courses were open in dealing with such particles, namely, to exclude them altogether, as in the 
experiments where the air was filtered through cottonwool, or else to destroy their vitality, as in the experiments where the air which was admitted to the organic fluids was not filtered, but subjected to great heat. There is no doubt that Lister's first view was that the main organisms which produced this decomposition reached the wound from the air or from dust deposited on surrounding objects, although he very soon modified that view as a result of practical experience. Proceeding, however, on the view that the main contamination came from the air, the question which he put before himself was, what was the best way of dealing with the infective particles; should they be simply kept out by filtration of any air which came in contact with the wound, or should they be killed before they got into the wound, and if they were killed what would be the best way of doing it? To filter the air did not seem at all a practical plan, and therefore he at once took up the line of killing the organisms before they got into the wound, and the simplest way of doing so seemed to be by the use of chemical substances which had the power of destroying these minute forms of life, and were termed antiseptics. Curiously enough, the first chemical substance to which his attention was directed was carbolic acid, which still holds its place as one of the most potent and generally most applicable antiseptics.

His views and methods were constantly undergoing expansion and modification as the result of experience. Starting with the crude notion of bacteria in general, he very soon found that there must be a great variety of different species of bacteria, each having its own life-history and producing different noxious effects or none at all, and that the harm following the entrance of bacteria into wounds was, in the main, not due to those which produced the putrefactive fermentation. However much he modified his views and his methods of dealing with wounds, he held to the leading view that no bacteria should gain admission to wounds in a living state, although it was not long before he recognised that it was an ideal aim and that practically bacteria must gain entrance to wounds to a certain extent in spite of all precautions. This led him to postulate the second factor which had to do with the avoidance of sepsis, namely, the power which the tissues themselves possess in preventing the development of these micro-organisms, and that was the point on which he laid the very greatest stress, and in connection with that he struggled for years to reduce, and, if possible, avoid altogether, irritation of the tissues in the wound, while at the same time, as far as possible, preventing the entrance of bacteria. Hence he was constantly changing his dressings and his methods, much to the perplexity of those who had not grasped the scientific ideas which were at the bottom of his researches.

These changes had a twofold object: one to obtain a more perfect sterilisation of the air, and the various objects which came in contact with the wounds, and the other to avoid as far as possible the use of irritating substances, and more especially to prevent them coming in contact with the wound itself, and thus interfering with the natural action of the tissues in destroying any bacteria which might enter them in spite of the various precautions.

A study of his collected works which were published a year or two ago will show the remarkable perseverance with which he followed out these aims, and as examples of scientific writing, they are probably unsurpassed. He possessed to a high degree the quality of genius, in not overlooking what to the ordinary mind would appear minor circumstances. If an experiment did not turn out as he expected, he proceeded at once to ascertain the cause, and he did NO. 2208, VOL. 88] not throw it aside as simply an accident. In this way he was led to a great variety of information which the ordinary observer would have missed altogether.

But Lister as a surgeon did not direct his attentions solely to the treatment of wounds and the avoidance of septic troubles in connection with them. As soon as he found that he could reckon with reasonable certainty on the avoidance of these troubles, he proceeded to consider in what way he could improve the existing methods of treatment, and naturally the immunity from septic diseases opened up a greatly increased range of operative work. Hence very shortly after the successful application of his theories to practice, we find him suggesting operations and procedures as regards the treatment of diseases which had not previously been attempted, and were looked on by the older surgeons as almost criminal. Such operations, for example, as osteotomy for deformities, the treatment of recent fractures, such as fracture of the patella, by operation, extensive operations for the removal of cancerous glands in connection with cancer of the breast, the intro duction of suprapubic colotomy, and a great many other procedures too numerous to mention.

Another point which should not be forgotten in connection with Lister is that it was his work which gave the main impulse to the development of the great science of bacteriology, a science which bids fair to occupy the most prominent place in medical work. It is true that he did not discover bacteria, nor did he take an active part in the bacteriological advances, but nevertheless he, along with Pasteur and Koch, may be looked on as a founder of the science. Until Pasteur's time the existence of bacteria and their life-history had been looked on as only an interesting but not very important study, and practically the only question asked with regard to them was whether they could arise spontaneously in organic fluids, or whether, like other living things, they must have had a progenitor. In other words, the battle raged for many years on the question of Spontaneous Generation. Pasteur was the observer who finally settled this question absolutely definitely, and showed that there was no such thing as spontaneous generation of living organisms, and that all organisms were derived from pre-existing ones, and he further showed that organisms were the causes of the ordinary fermentations, including the putrefactive fermentation.

Until, however, Lister seized on the facts demonstrated by Pasteur, and applied them to the treatment of wounds, practically no one had looked on these organisms as of any importance in disease. As soon as Lister showed that the exclusion of these organisms from wounds meant the disappearance of a variety of diseases to which man had been previously subject, the study of these organisms naturally advanced with great rapidity. Lister, for some years, did work in that direction himself, but comparatively little progress was made until it was taken up by Pasteur, who, with his wonderful insight, drew deductions from his observations of far-reaching value. But the great progress dates from the time when Koch appeared in the field, and demonstrated definitely the relation of these organisms to disease, and showed how they could be detected and how they oould be stained and cultivated. Since that time the science has gone ahead at a very rapid pace; but without Pasteur, Lister, and Koch, and more especially without the practical demonstration of the great importance of these organisms by Lister, it is impossible to say whether this science would have been in existence at all at the present moment.

I need not say anything about Lord Lister as a 
man. That he was conscientious to a degree, and considered any matters brought to his notice without any personal bias, is well known to all those who had dealings with him. That he never believed ill of anyone I can testify from long association with him; that those who opposed him were mistaken in their views was only a natural conclusion from the belief that he had in his own, but that any other motive influenced them in opposing him did not enter into his calculations. Above all, he was full of sympathy for suffering humanity. He spent an enormous amount of time in his hospital work, not only in making his observations and in watching the progress of the wounds under different methods of treatment, but also in relieving the suffering of the patients. $\mathrm{He}$ was often remonstrated with by the committees of the hospital to which he was attached for keeping patients in the hospital for a very long time, but he looked on the hospital as an institution for curing the patients, and would not let anyone leave so long as he was likely to obtain further benefit from remaining in it. When he came to London, there were several patients in his wards in Edinburgh, chiefly cases of spinal disease with abscess, who would naturally have been sent home after he left. Rather than allow them to run the risks consequent on that procedure, Lord Lister had several of them transported to London and placed in nursing homes at his own expense, and they were kept there for months, and in one case years, until the disease was cured.

W. Watson Cheyne.

\section{Funeral Service in Westminster AbBey.}

Upon the news of Lord Lister's death, the Dean of Westminster (Bishop Ryle) at once offered the signal honour of burial in Westminster Abbey. This, however, was rendered impossible by the circumstance that it was Lord Lister's wish that he should be laid to rest at West Hampstead Cemetery, where his wife had been interred in I893. Accordingly, the decision was taken to hold a funeral service, and to accord the full ceremonial which would have attended an actual burial within the Abbey had that been practicable.

The body was taken to the Abbey on the evening of Thursday last, in the charge of the near relatives, being received by the Dean and clergy. It was then deposited in the Chapel of St. Faith, where an offering of prayer was held.

Impressive indeed was the funeral service next day. The King was represented by Sir Frederick Treves, Queen Alexandra by Sir Francis Laking, and Princess Louise (Duchess of Argyll) by Mr. Oswald Balfour. The Prime Minister, Lord Lansdowne, the Lord Mayor of London, and the Lord Provost of Edinburgh attended. A gathering representative of the Corps Diplomatique, Government departments, British universities, scientific and medical societies, and many private individuals, all drawn by the same desire to pay a final tribute of respect, filled the Abbey in every available part.

The foreign delegates who attended were :-

M. Gabriel Lippmann, For.Mem.R.S., president, Paris Academy of Sciences, with Profs. Chaveau, For.Mem.R.S., Dastre, and Roux; Prof. Pozzi, Academy of Medicine, Paris; Prof. E. Roux, Pasteur Institute; Prof. Garré, president, German Congress of Surgeons; Prof. H. Treub, Dutch Medical Society, Amsterdam, and University of Amsterdam.

Many foreign learned societies were also represented, in addition to the foregoing, through the nomination of men of science in this country.

NO. 2208, VOL. 88$]$
On the part of the Royal Society there were present :-

Sir Archibald Geikie (president, who took part as a pall bearer); Sir Alfred Kempe (treasurer); Sir Joseph Larmor and Sir John Bradford (secretaries); Sir William Crookes, O.M. (foreign secretary); Dr. Lazarus Fletcher; and Sir John Kirk.

The pall-bearers and chief mourners were as subjoined :-

\section{Pall Bearers.}

Lord Rayleigh, O.M. (past president of the Royal Society, and Order of Merit); Lord Rosebery (Chancellor of the University of London); Lord Iveagh (Lister Institute) ; Sir Archibald Geikie (president of the Royal Society); Principal Sir Donald MacAlister (University of Glasgow); Sir Watson Cheyne (King's College, London); Mr. R. J. Godlee (president of the Royal College of Surgeons); Prof. Francis M. Caird (University of Edinburgh).

Sir Hector Cameron (University of Glasgow), who was to have been a pall bearer, was prevented by illness from fulfilling the duty.

\section{Chief Mourners.}

Mr. J. J. Lister, F.R.S., Dr. Arthur Lister, Miss Lister, Mr. R. G. Godlee, Mr. J. Lister Godlee, Mr. Lister Harrison, Mrs. Phear, Colonel and Mrs. Montagu Broun, Mr. P. Godlee, and Miss Christina Godlee.

At the Chapter House a procession was formed, comprising the chief mourners and immediate friends, together with representatives specially designated from civic, learned, and other institutions. Preceded by the choir and officiating clergy, the coffin was borne through the Cloisters from the Chapel of St. Faith, the while the hymn "Brief life is here our portion" was sung. From the nave to the choir the opening sentences of the Burial Service were sung, in procession, to the setting by Dr. Croft. The coffin was deposited temporarily on a high catafalque at the steps of the altar. On the pall lay the insignia of the Order of Merit, Knight of the Prussian Order "pour le Mérite," and Knight Grand Cross of the Order Danebrog.

A wreath of orchids and lilies, sent by the German Emperor, and brought to the Abbey by his Excellency the German Ambassador, was carried before the bier on its way to the choir. Floral tributes came also from the Pasteur Institute, Paris, the German Society of Surgery, and Dutch Medical Society.

After the lesson, an anthem by Handel was sung. Composed for the funeral of Queen Caroline in 1737 , it was chosen for the special appropriateness of the words. These are appended:- "When the ear heard him, then it blessed him: and when the eye saw him, it gave witness of him. He delivered the poor that cried: the fatherless and him that had none to help him. Kindness, meekness, and comfort were in his tongue. If there was any virtue, and if there was any praise, he thought on those things. His body is buried in peace, but his name liveth evermore." Goss's anthem, "I heard a voice," followed.

At the conclusion of the service, and whilst the coffin was being borne from the Abbey, the "Dead March " in Saul was played by Sir Frederick Bridge.

The following acted as stewards in the choir, transepts, and Chapter House :-

King's College Hospital: Dr. Gillett, Major Lyne, A. C. McAllister, G. Matthews, H. P. Morton, V. E. Negus, H. A. Richards.

University College Hospital: Dr. Chubb, Dr. Cowell,

A. Courts, H. Waller, G. E. O. Williams.

Royal Society: T. E. James, F. A. Towle, A. H. White.

Simultaneously with the rites in the Abbey, a memorial service was held in St. Giles's Cathedral, Edin- 